\title{
Metastatic Oropharyngeal Squamous Cell Carcinoma
}

National Cancer Institute

\section{Source}

National Cancer Institute. Metastatic Oropharyngeal Squamous Cell Carcinoma. NCI

Thesaurus. Code C150202.

A squamous cell carcinoma of the oropharynx which has spread from the orig inal site of growth to another anatomic site. 